\title{
Aile Hekimliğinde Önemli Bir Konu: Aile Rehberliği”
}

\section{An Important Issue in Family Medicine: Family Guidance}

Oğuz Tekin, Mehmet Onat Çakıt, İsmail Arslan, Gülay Gülmez, Vildan Şahin, Kamile Şahin, Özlem Palaz, Dilek Nurlu, Arzu Kuzulu, Zeynep Doğangüzel, Ümit Eren, Saih Dilber, Havva Öznur.

Ankara Eğitim ve Araştırma Hastanesi

\section{Özet}

Toplumun temeli olan aile, günümüzde birçok tehditle karşı karşıyadır. Birçok kurumun aile sağlığı ve rehberliği ile ilgili çalışmaları vardır. Aile hekimleri de koruyucu hekimlik hizmetleri içerisinde psikososyal yönden hizmet vermelidir. Ailede problemleri belirlemeli, tehdit oluşturabilecek durumları tespit etmeli ve önerilerde bulunmalıdır. Bu makalede aile hekiminin belirtilenleri yapabilmesi içinsağlıklı bir ailenin oluşumunda aile rehberlik hizmetinin önemi anlatıldı.

Anahtar kelimeler aile, rehberlik,psikososyal

\begin{abstract}
The family, which is the basis of the society, faces many threats today. There are many studies about family health and guidance of various organizations. Psychosocial aspects of family physicians should also serve in preventive medicine services. They should identify the problems in the family, identify the situations that pose a threat and provide suggestions. This article describes the importance of the family guidance service for the family physicians for the development of a healthy family.
\end{abstract}

Keywords Family, guidance, psychosocial

\section{Giriş}

Aile, toplumun en küçük birimidir. Anne, baba ve çocuklardan meydana gelir.Aile, aynı zamanda sosyal bir sistemdir.

Aile yapısının fonksiyonları şu şekilde ele alınabilir;

1. Problemleri Çözme

2. Aile içi İletişim

3. Roller

4. Duygusal tepki verebilme

5. Gereken ilgiyi gösterme

6. Davranış kontrolü ${ }^{(1)}$

Aile Müessesesinin görevleri bir makalede şöyle ele alınmıştır;

- Nüfusu yenilemek

- Milli kültürü devam ettirmek

- Çocukların sosyalleşmesini sağlama

- Psikolojik/ekonomik ve biyolojik tatmin ${ }^{(2)}$ olarak ele alınmıştır.

\section{Aile Rehberliği Kavramına Bir Yaklaşım}

Günümüzde, toplumun en küçük birimi olan ailelerin sağlıklı bir yapıda olması için, ailelerin gerek kuruluş aşamasında gerekse ailesel döngü aşamalarında sağlıklı davranış modelleri göstermesi ve sağlıklı fonksiyon görmesi gerekmektedir. Aileyi bu yönlerden ele almak, aile bireylerine bu konuda danışmanlık vermek, aile sağlığını koruma ve geliştirme ile ilgili önlemler almak, mevcut problemleri ortaya koymak ve çözüm yollarını göstermek, gerek eğitim, gerek rehberlik, gerekse diğer çalışmalar ile uygun ve sağlıklı davranışlara yöneltmek, ailelerden başlayarak toplumun daha iyi ve sağlıklı hale gelmesi için bir bakış açısı geliştirmek aile rehberliğinin konusu olarak ele alınabilir. Bu konuda ayrıca değişik kurum, disiplin ve mesleklerin (psikolog, diyanet, öğretmen, vb) uyguladığı yaklaşımlar söz konusudur.

\section{Aile Rehberliğine Olan İhtiyaç}

Sağlıklı bir aile yapısı, sağlıklı bir toplumun temelidir. Ailelerin sağlıklı olması, sadece aile bireylerinin beden olarak sağlıklı olması olarak anlaşılmamalıdır. Aile içi psikososyal mekanizmaların sağlıklı işlemesi de bu konuda düşünülmesi gereken bir yöndür. Ancak ailede psikolojisi, düşünce mekanizması ve kişiliği farklı pek çok birey söz konusu olduğu için zaman zaman aile içi çeşitli problemler yaşanabilmektedir. Günlük rutin işleyiş içerisinde, içeriden bir bakışla aile bireylerinin bu konuları kendi başlarına çözmesi her zaman mümkün olamamaktadır. Çözülemeyen problemler ise karşımıza boşanma, aile içi şiddet, aile bireylerinin görevlerinin yerine getirememesi, sağlıksız ve psikolojik yönden hastalıklı bireylerin yetişmesi /belirmesi,

* Bu makale, ANKARA E.A.H. Aile Hekimliği Kliniği projelerinden “Aile Rehberlik” projesi grup çalışmasının ürünüdür. Proje hakkında ayrıntılı bilgi almak için: http://ankarahastanesi.blogspot.com.tr/p/projeler.html adresini ziyaret ediniz. 
ekonomik kayıp, verimsizlik, genel olarak toplumsal yapının bozulması vb. olarak çıkmaktadır. Bu konuda profesyonel yaklaşımlara ihtiyaç vardır. Bu yaklaşımlarda ise değişik bakış açıları olan disiplinlerden oluşan ekip çalışmasına ihtiyaç vardır. Bu disiplinlerden biri olan hekimlerin ve özellikle aile hekimlerinin de bu konuda çalışmalar yapması problemin çözümünü kolaylaştıracaktır. Bu kapsamda, Ankara E.A.H. Aile Hekimliği kliniği olarak "Aile Rehberlik Projesi" çalışmalarını başlatmış bulunuyoruz. Link: http:// ankara hastanesi. blogspot. com/p/projeler.html. Aşağıdaki bölümler, Proje grubunun değişik zamanlarda yürüttükleri tartışma, beyin fırtınası ve çeşitli akademik çalışmaların sonucunda ortaya çıkmıştır ve projenin bundan sonraki safhalarına yol gösterici niteliktedir.

\section{Günümüzde Ailelerin Belirgin Problemleri}

- Eşlerin görevlerini, karşılaşacakları problemleri ve çözüm yollarını yeterince bilmeden yuva kurmaları $(\mathrm{Bu}$ konuda değişik anlayışlar olmakla birlikte, toplumun genel olarak kabul ettiği bir çalışma yapılabilir)

- Sağlıksız iletişim

- Çocukların psikolojik olarak tam sağlıklı bir şekilde yetiştirilememesi

- Ebeveyn rollerinin yeterince belirlenip çocuklara uygulanamaması ile ilgili problemler

- Aile içi şiddet

- Ebeveynlerin kötui örnek olması (Alkolizm, sigara bağımlılığı vb)

- Hedef ve ideal eksikliği (Okula neden gidiyor, ileride ne olacak, topluma nasil hizmet edecek vb)

- Ebeveyn mesleklerinin aile üzerine etkileri

- Aile içi sağlık problemlerinin aile üzerine etkileri

- Ekonomik problemler

- Aile yapısının aile üzerine etkileri (Geniş aile, çekirdek aile vb)

- Diş etkenlerin olumsuz etkileri (Televizyon, internet, terör vb)

- Değişen toplum yapısının aile üzerine etkileri

- Ailedeki psikiyatrik problemler ile güçlüklerle başa çıkma iliş̧isi

İlk planda akla gelenler bunlar olmakla birlikte, değişik çalışmalarla bu konu ileride daha ayrıntılı bir şekilde irdelenebilir.

\section{Aile ve Aile Hekimi}

Aile hekimliği sisteminde her hekime belli sayıda aile bağlanmakta ve hekim adeta ailedenbir kişi haline gelmektedir. $\mathrm{Bu}$ sebeple aile konusunda planlanacak olan psikososyal hizmetlerde, aile hekimliği adeta biçilmiş bir kaftandır. Aile hekimleri, ailelere hem fiziksel hem de psikolojik sağlık sorunları konusunda yardımcı olabilirler. Üstelik bu konularda aile ziyaretlerinde olduğu gibi doğrudan yaklaşımda bulunabilme imkânları da vardır. Günlük hekimlik pratiği içinde, rutin problemlerle uğraşmanın yanı sıra meselenin ihmal edilmiş olan bu yönü ile de uğraşmak gerekli hale gelmiştir. Bu konuda aile hekimliği eğitim ünitelerinde çeşitli projeler düzenlenebilir.

Rehberlik Konusunda Akla Gelen Bazı Yaklaşımlar

- Bağlı nüfustaki Ailelerin yapısını -psikososyal açıdantanımak

- Aile yaşam döngüsünün hangi aşamada olduğunu vevarsa bu döneme ilişkin sorunları belirlemek

- Yardım almak için başvuran ailelerin sorunlarını (aile içi şiddet vb) belirlemek

- Sorunların çözüm yolları konusunda rehberlik yapmak

- Aynı sorunu paylaşan aile bireylerini bir araya getirmek ve sosyal ortam temin etmek

- Eğitici seminerler düzenlemek

- Hedef ve ideal kazandırma çalışmaları (Meslek konusunda yol göstermek vb)

- Yaşam tarzı değişiklikleri (diyet, egzersiz, sosyal aktiviteler vb)

- Sağlıklı iletişim çalışmaları (günlük kitap okuma, aile içi sohbet, hediyeleşme, oyunlar vb)

- Çocuklar için ödül ve ceza sistemini düzenlemek

- Çocukların içinde bulundukları yaş dönemine göreebeveyn yaklaşımlarını düzenlemede yol göstermek

- Değerlendirme ve farkındalık mekanizmalarının gözden geçirilmesini desteklemek

- Çevre, meslek, ekonomik ve benzeri düzenlemeler yapmak (sosyal destek mekanizmaları vb)

- İletişim teknolojilerini uygun şekilde kullanmak (güvenli internet vb.)

- Çocukların mesleki planlamalarını yapmak

- Askerlik sırasında ebeveynlik eğitimine destek vermek Geliştirilecek olan çeşitli projelerle, bu konuda yapılabilecekler daha ayrıntılı şekilde ele alınabilir.

\section{Günümüzde Ailelerin Sağlıklı Yapısını Tehdit Eden Faktörler}

- Uzun süre televizyon seyretme

- Yararlı programların yanısıra olumsuz etkileri düşünülmeden şiddet, aile sırları ve benzeri içerikli çeşitli programların da kontrolsüz şekilde yaygınlaşması

- Internet gibi sanal ortamların kötüye kullanıma açık olmas1

- Sağlıklı iletişim yollarının bilinmemesi veya iletişimsizlik

- Sağlıksız davranış örneklerinin yaygınlaşması, sağlıklı davranış örneklerinin bilinmemesi

- Monotonluk 
- Aile yaşam döngüsüne uygun reaksiyon verememe

- Değişen değerler

- Örf, adet ve geleneklerin etkisi

- Aşırı harcamaların teşvik edilmesi

- Aileye dışarıdan sağlıksız müdahaleler (büyük ebeveyn, vb. kişiler)

- Zamanın uygunsuz kullanımı (biyolojik takvim)

- Dağınıklık ve aile bütünlüğünün korunmasında çalışan kesimde olan yetersizlikler

- Maddi/manevi tatminsizlik

- Bilgi Eksikliği

- Eğitimsizlik

- Terör gibi topluma yönelik, güvenliği tehdit eden genel olayların ailelere etkisi

Aile Kurmadan önce Alınan / Alınabilecek olan Eğitimlerin içerik ve kaynakları

- Anne babanın rol model alınması

- Kültür ortamının sağlanması ve ilk bilgiler

- Aile ve Sosyal Politikalar Bakanlığı'nın çalışmaları (iletişim, sağlık, problem çözme hakkındaki çalışmalar)

- Anne/babanın görev ve sorumlulukları

- Aile yapısının devamı için gerekli görevler ve bunların paylaşımı

- Tolerans ve hoşgörü gösterme

- Bencillik ve diğ ergamlık

- Roller, iletişim, gereken ilgiyi gösterme, davranış kontrolü gibi ailenin temel fonksiyonları

- Zamanın etkin kullanımı

- Sosyal ortam paylaşımı

- Sorun çözebilme

İlk planda akla gelenler olmakla birlikte zaman içinde ihtiyaçlara göre yeni konular gündeme gelebilir.

Aile Rehberliği Konusunda katkıda bulunan /bulunabilecek ve işbirliği yapılacak olan meslek ve Kurumlar

Aile rehberlik hizmetlerinde kurumlar arası ilişkiler ve ortak projeler önemlidir. ${ }^{(3)}$ Ulusal platformda aile rehberliği konusunda bazı kurum ve kuruluşlar akla gelebilir $^{4}$

- Aile ve Sosyal politikalar bakanlığ

- Milli Eğitim Bakanlığı

- Okullar (Rehberlik hizmetleri)

- Aile Terapistleri

- Psikologlar

- Diyanet işleri Din Hizmetleri Dairesi Başkanlığ ${ }^{3}$

İlk planda akla gelen mesleki kişi ve kurumlardır. Örnek vermek gerekirse, 20 Mart 2012 tarihli 6284 sayılı "ailenin korunması ve kadına karşı şiddetin önlenmesine dair kanun" yürürlüğe girmiştir.Ayrıca Aile ve Sosyal Politikalar Bakanlığı tarafından aile içi iletişimi artırmak ve bu konuda problemi olan ailelere "Aile Danışma Merkezleri" aracılığı ile hizmet verilmektedir. Yine ayni bakanlık tarafından "Toplum Merkezleri" kanalıyla çeşitli eğitim programları düzenlenmektedir. ${ }^{5}$

Aile Rehberlik Hizmetlerinin Geleceğimize Katkıs1

Aile rehberlik hizmetlerinin gelecekteki hedeflerinde aşağıda belirtilenler yer alabilir

- Aile içi şiddetin önlenmesi

- Aile içi iletişimin artırılması

- Beden ve ruh yönünden sağlıklı nesillerin yetiştirilmesi

- Toplum olarak mental sağlığının daha iyi bir duruma getirilmesi

- Kişilere aile sağlığı bazında hizmet vermek için baz oluşturmak

- Çeşitli kurum ve kuruluşlara bu konuda danışmanlık vermek için zemin oluşturmak

- Aile ile ilgili çeşitli konularda aktif koruyucu tedbirler almak

- Ailelerin çeşitli risk faktörlerini analiz ederek sağlıklı yapının devamını sağlamak

- Aile sağlığ bilgiyi üretmek

Bunlara ulaşmak için birinci basamakta iyi işleyen bir sağlık hizmet sunumu kaçınılmazdır. ${ }^{6} \mathrm{Bu}$ nedenle de aile hekimliğinde aile rehberlik bakış açısının gelişmesi ve yaygınlaşması desteklenmelidir.

\section{Kaynaklar}

1) Miller, /.W.,Epstein, N.B., Bishop, D.S., Keitner, G.1. (1985). The Mc Master Family Assesment Device: Reliabilityand validity. Journal of Maritaland Family Therapy. Vol 11, no.4, 345-356

2) Erkal M.E.Sosyoloji,3.bask1, Filiz Kitabevi, İstanbul 1987:76

3) Diyanet İsşeri Başkanlığı, Din Hizmetleri Dairesi Başkanlığı. Kadın ve Aileye Yönelik Çalışmalar 2007-2009

4)T.C. Başbakanlık Kadının Statüsü Genel Müdürlüğü. Kadına Yönelik Aile İçi Şiddetle Mücadele Ulusal Eylem Planı 2007-2010, Kadına Yönelik Aile İçi Şiddet Mücadele Projesi, ISBN 978-975-19-4199-2

5) T.C Aile Ve Sosyal Hizmetler Bakanlığı. TBMM Soru Önergesi Cevabi 20.11.2012

6) T.C Sağlık Bakanlığı. Aile Doktorları için Kurs Notları. Ankara, 2004
Yazışma Adresi/Correspondance Dr.Oğuz Tekin Ankara Eğitim ve Araştırma Hastanesi Aile Hekimliği Kliniği

E-posta: oguztekin82@hotmail.com Geliş Tarihi: 28.06.2013 Kabul Tarihi: 19.11.2013 